\title{
Creative economy: thematic perspectives addressed and research methodologies adopted
}

\author{
Luciana Lima Guilherme*
}

\author{
*Correspondence: \\ guilherme.luciana@gmail.com \\ Program of Public Policies, \\ Strategies and Development, \\ Rio de Janeiro Federal University \\ (Universidade Federal do Rio de \\ Janeiro - UFRJ), Rio de Janeiro, \\ Brazil
}

\begin{abstract}
This article aims to analyze the bibliography concerning creative economy and its related sub-themes, identifying the main researched themes and research methodologies. For this, the author conducted bibliographic research using the CAPES [Higher Education Personnel Improvement Coordination (Coordenação de Aperfeiçoamento de Pessoal de Nível Superior-CAPES) (under the Brazilian Ministry of Education)] portal, prioritizing journals with high impact factor. As a result, a predominance of studies for the construction and understanding of conceptual bases associated with creative economy, creative cities, regional development, industries analysis and issues facing the business management were found. A majority of the selected articles utilize qualitative methodologies.
\end{abstract}

Keywords: Creative economy, Creative industries, Creative cities, Creative classes, Cultural industries, Public policies

\section{Background}

The subject of creative economy has been at the focus of discussions in international organizations and communities in recent decades, highlighting itself as strategic for the economic and social development and growth of both developed and developing countries. The academic community has expanded this debate beyond fundamental reflections in an effort to achieve a greater understanding of the concepts involved, their impacts, and their limits within each country's historical, political, economic, social and cultural contexts.

Emerging in the last decade of the twentieth century, the concept of creative economy-an economic system based on the synthesis between economics, culture, science and technology — has gradually gained recognition as an increasing number of individuals and organizations come to understand creativity as a motor that fuels development processes (UNCTAD 2010). From a sectorial perspective, creative economy is understood by many as an expansion of cultural economy because, in addition to encompassing the traditional cultural sectors (music, dance, circus, visual arts etc.), creative 
economy also includes sectors related to information and communication technologies (such as digital games, animation, and software development) as well as culturallybased sectors related to traditional industries (such as fashion, design, architecture, and advertising).

As an alternative model of development, creative economy converges with the concept of "Economy of Experience" to surpass a model based on the production of commodities in favor of assuming a model in which goods and services have as their main value their aesthetic-symbolic nature and their capacity to create experiences rather than just products (Kamel and Souza 2012).

If on one hand this "new economy" is understood within a post-industrial context as a propeller of growth in developing countries and defended as a solution to the challenges of economic repositioning, creative economy is on the other hand regarded with suspicion due to the tensions and fears it raises about the production of and access to culture as well as the commercialization of goods and services, the latter of which submits creative goods and services to a purely mercantile logic (Bendassolli et al. 2009).

In this way, the debates, discourses, and narratives surrounding creative economies makes itself present in both technical and academic publications. At times the discourse is in favor of creative economies and of the possible development and growth it can foster. At others, however, the creative economy is criticized for catalyzing exclusionary and neo-liberal policies that are subjected to mercantile market practices.

The debate has thus revolved around reflections about the polarisations and conceptual confusions surrounding the identification of characteristics of the creative economy and the definitions and implications of creative economy, cultural economy, and related topics such as cultural industries, creative industries, creative cities, and creative classes.

Although still growing, the academic bibliography produced on the subject of creative economy represents the beginning of a reflection that invites more discussion and research, especially given the extent and the ambiguity of the theme. Considering the publications classified by the Qualis System of the Coordination of the Improvement of Higher Level Personnel (Sistema Qualis da Coordenação de Aperfeiçoamento de Pessoal de Nível Superior-CAPES), one notices a prevalence of articles that deal with aspects within the scope of the subject matter. More specifically, there is a plethora of case studies that present sectoral analyses, the development of management strategies, and the strengthening of entrepreneurial ventures in cultural and creative sectors.

The objective of this article is to analyze the bibliography produced on the subject of creative economy, identifying research and research methodologies used in [these] reflections on the creative economy, and sub-themes related to creative economy (creative industries, cultural industries, creative cities, creative classes, innovation, education 
and professional development among others). This bibliographic research was conducted in the database Portal Capes in journals whose classification, according to Qualis criteria, complied with the following categories: A1, A2, B1 and B2. The use of these criteria for the selection of articles and periodicals was intended to ensure that the articles were selected and analyzed in accordance with the high quality standards and requirements of academic production.

This work is structured in four parts: the first corresponds to an introduction to the theme of creative economy[economies], consisting of a brief history of the main concepts and public policies formulated in the world and in Brazil; the second presents the methodology used for this bibliographic research, identifying criteria and information sources used; the third presents an analysis of the panorama of the studies, research methodologies, and debates on and surrounding creative economies, indicating both central and sub-themes; finally, the fourth part refers to the conclusions of this study, indicating/pointing to opportunities for the advancement of studies on creative economy and related sub-themes.

\section{Creative economy: the construction of a concept and of policies for development}

When we analyze the history and evolution of the concepts associated with the theme of the creative economy in the world, we can see how creative economy has been increasingly understood as a viable measure of growth for both emerging and developed countries. More people are beginning to consider creative economy as a function of public policies that have drawn inspiration from concepts such as creativity, sustainability, cultural diversity and innovation.

The creative economy is perceived as an economy based on abundance rather than on the scarcity of resources. This is because the its main inputs-creativity and human knowledge-are infinite. The creative economy's greatest value is its association with a diversity of cultural expressions in different localities and regions. The creative economy is collaborative because it consists of a series of arrangements between persons, institutions and governments, and increasingly potent because it reconciles national strategies with global international processes.

Australia is considered by many as the founding father of creative economy. In 1994, the Australian Government, as part of an initiative of the Ministry of Culture, coined the concept of Creative Nation as the basis of a policy geared towards upgrading the role of the State in the cultural development of the country. At the core of this policy is the Australian Government's responsibility to foster and increase access to Australian culture at a national level, ensuring that: (1) innovation and ideas are continually encouraged; (2) self-expression and creativity are nurtured; (3) patrimony and the development of patrimony is preserved, and (4) all Australians have the opportunity to participate in and benefit from the creative economy, all of which will invigorate national life and uplift Australian citizens. 
The Creative Nation policy has expanded considerably since its inception. Between 1994 and 1995, the Department of Communications and Arts expanded the role of the Creative Nation policy and direct expenditure for this new economy was estimated at over a billion [australian] dollars (Australia 2013). Beyond the Office of the Prime Minister, additional funding for Australian cultural development was provided through other means, including external relations, trade, education, employment, environment, and sport.

The intended objectives of this cultural development policy fall into five main categories:

- nurture creativity and excellence

- allow all Australians to enjoy as many cultural experiences as possible

- preserving the patrimony of Australia

- promote the expression of cultural identity and diversity of Australia

- promote sustainable development and creative industries, including those that evolve with the emergence of new technologies.

Creative Nation quickly gained recognition among the academic and economic world and ended up reaching the United Kingdom. It was brought to England by New Labour, a programme for the renewal of the Labour Party who, in their 1997 pre-election manifesto, identified creative industries as a particular sector of the economy and recognized the need for specific public policies that tapped into its growth potential.

Between 2007 and 2010, then-British Prime Minister Gordon Brown established a Department of Creative Industries and Tourism under the Ministry of Culture, Media, and Sport (Corazza 2013). The Creative Economy Programme identifies the creative sectors with the highest growth rates and clarifies the distinctions between economic and cultural objectives. In addition, the Department of Creative Industries and Tourism created "Centers of Excellence" for creativity/innovation in all regions of the UK. A third focal point of this program was the analysis of the legal frameworks of intellectual property and their impact on how the private initiative and society are able to reconcile their diverging interests. While on one hand, there is a growing movement focused on increasing digital rights and measures of protection of technical intellectual property from easier and often illegal ways to access and use digital content, on the other hand there is public interest in promoting greater and more affordable access to this digital content.

The success of Australia and the UK's creative economies led to the development and implementation of public policies for creative industries throughout the world. In 2008, the United Nations Conference on Trade and Development (UNCTAD) launched the first world report on the creative economy, Creative Economy Report, in an effort to compile information/data on the creative economy from a global perspective/within a global context. This report was a milestone in the recognition of the strategic relevance of creative economy as a vector for development with a promising average annual growth mean of $10 \%$. In 2010, the UNCTAD released a second edition of the report, 
expanding an already lively discussion of the importance, relevance, and feasibility of creative economy.

The creative economy is a horizontal, evolving concept based on creative assets that can potentially generate economic growth and development.

- It can stimulate the generation of income, the creation of jobs and the exporting/ exportation/export of profit, simultaneously promoting social inclusion, cultural diversity and human development.

- It embraces economic, cultural and social aspects that interact with the objectives of technology, intellectual property and tourism.

- It works in conjunction with a set of economic activities based on knowledge, with an/the added dimension of development and interconnections on both macro and micro levels for the economy in general.

- It is a viable development option that demands politically innovative and multidisciplinary answers in addition to interministerial action.

- "At the center of the creative economy, there is creative industry/Creative industries are at the center of the creative economy." (UNCTAD 2010, p. 10)

Creative industries - the core of creative economy-are sustained by public policies and systems of classification that vary by country.

The Fig. 1 outlines the classification proposed by UNCTAD.

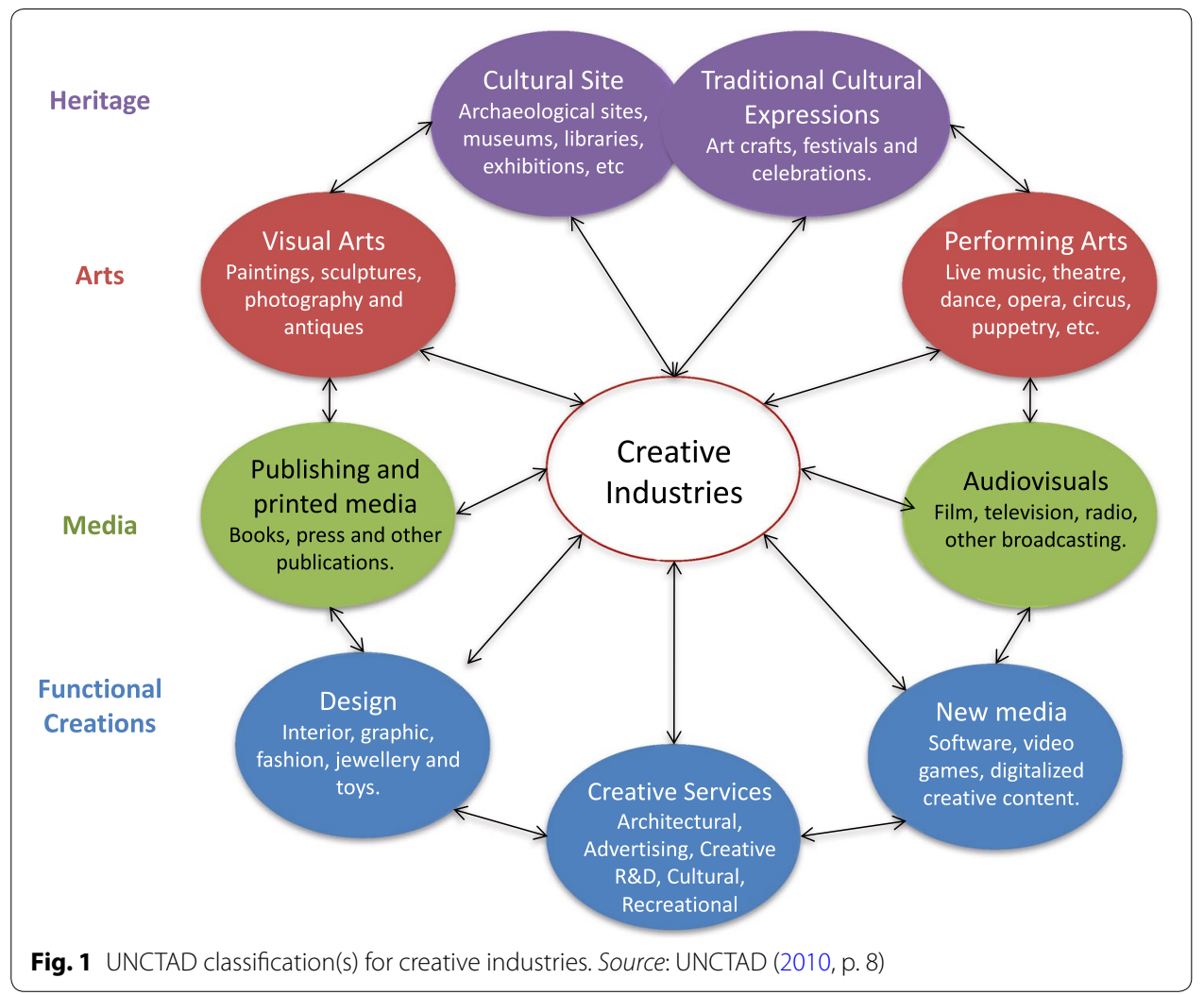


According to UNCTAD (2010, p. 8), creative industries:

- Are cycles of creation, production and distribution of products and services that use creativity and intellectual capital as primary inputs;

- Constitute a series of activities based on knowledge centered, among other things, in the arts, which potentially generate profit and intellectual property rights;

- Constitute tangible products and intellectual or artistic intangible services with creative content, economic value and market goals.

- Position themselves at the crossroads of artistic, service-oriented, and industrial sectors;

- Constitute a new, dynamic sector in the world market.

A remarkable fact about the creative economy during this period is that exports of creative goods and services kept growing in spite of the world financial crisis in 2008, which caused a decrease (word choice) in the international market.

World exports of creative products and services reached a revenue of $\$ 592$ billion in 2008-more than the double the amount reached in 2002-which indicates an annual growth rate of $14 \%$ over six consecutive years. These numbers are evidence of the fact that creative industries present an enormous potential for developing countries that seek to diversify their economies and take a leap into one of the most dynamic sectors of world economy.

That being said, Brazil is still incipient in its data production on creative economies. The Federation of the Industries of Rio de Janeiro State [Federação das Indústrias do Estado do Rio de Janeiro-FIRJAN] (2013) realized in 2008 a pioneer study called "The Creative Industry Chain in Brazil" as a Brazil's first exercise in economic data projection, produced from data by the Brazilian Geographic and Statistical Institute [Instituto Brasileiro de Geografia e Estatística-IBGE] and from data extracted from the Annual Relation on Social Information [Relação Anual de Informações Sociais-RAIS] (Ministry of Work and Employment). By 2012, a complement of this research that considered database information from 2011 was published considered the database information of 2011.

Analysing the following Table 1, it may be verified the percentual contribution of the creative sectors' GDP in the formation of different countries' total GDP, including

Table 1 Creative nucleus's GDP and share in the GDP, selected countries (2011)

\begin{tabular}{lcc}
\hline Country & Creative GDP (R\$ billions) & Share of GDP (\%) \\
\hline United States & 1011 & 3.3 \\
United Kingdom & 286 & 5.8 \\
France & 191 & 3.4 \\
Germany & 181 & 2.5 \\
Brazil & 110 & 2.7 \\
Italy & 102 & 2.3 \\
Spain & 70 & 2.3 \\
Holland & 46 & 2.7 \\
Norway & 32 & 3.2 \\
Belgium & 27 & 2.6 \\
Sweden & 26 & 2.4 \\
Denmark & 21 & 3.1 \\
Austria & 15 & 1.8 \\
Greece & 6 & 1
\end{tabular}

Source: FIRJAN; UNCTAD, based on the GDP projection (2011) made by World Bank 
Brazil's. It is interesting to note that, even without precise data about Brazil, the country already figures in the fifth position on the ranking presented below.

In 2014, FIRJAN launched a new study, the Creative Industries Mapping in Brazil, where it is shown info and data that express the evolution of creative field in Brazil from 2004 to 2013. The share of GDP of creative sectors on Brazil's entire GDP, in this decade, has gradually grown reaching the point of $2.6 \%$ in 2013, as it can be seen on the Fig. 2 .

Considering the fact that FIRJAN's research is based on formal data on the creative economy, it is likely that creative economy's contribution to GDP would be even greater if it also considered data obtained from productive sectors of the informal economy. In any case, data on the formal market are meaningful and shows already the strength of an economy that has only been growing on. The Creative Industries' Mapping in Brazil (FIRJAN 2014), presents relevant data that demands more attention, relatively to the participation of creative employees in the total amount of employees per state in the country as well as the median monthly income of these professional. According to Graphic 3, the two states with bigger percentual participation-as expected-are Rio de Janeiro and São Paulo.

In 2014, FIRJAN launched The Mapping of Creative Industries in Brazil (FIRJAN 2014), a study that presents the growth in both the number and the median monthly income of employees working in creative fields in Brazil from 2004 to 2013. According to Fig. 3, the two states with biggest percentual participation are-as expected-Rio de Janeiro and São Paulo.

Illustrating the median monthly income of professionals working in Brazil's cultural and creative sector, Fig. 4 shows that there was significant growth in practically all Brazilian states between 2004 and 2013.

A comprehensive approach to the economic evolution of creative sectors in Brazil requires an understanding of the evolution of cultural consumption. The Fig. 5 below shows a study of FGV Projetos (2015) produced a study on the economic aspects of Brazilian culture and noticed an increase of $\$ 1$ billion in Brazilian consumption of culture between 2003 and 2009.

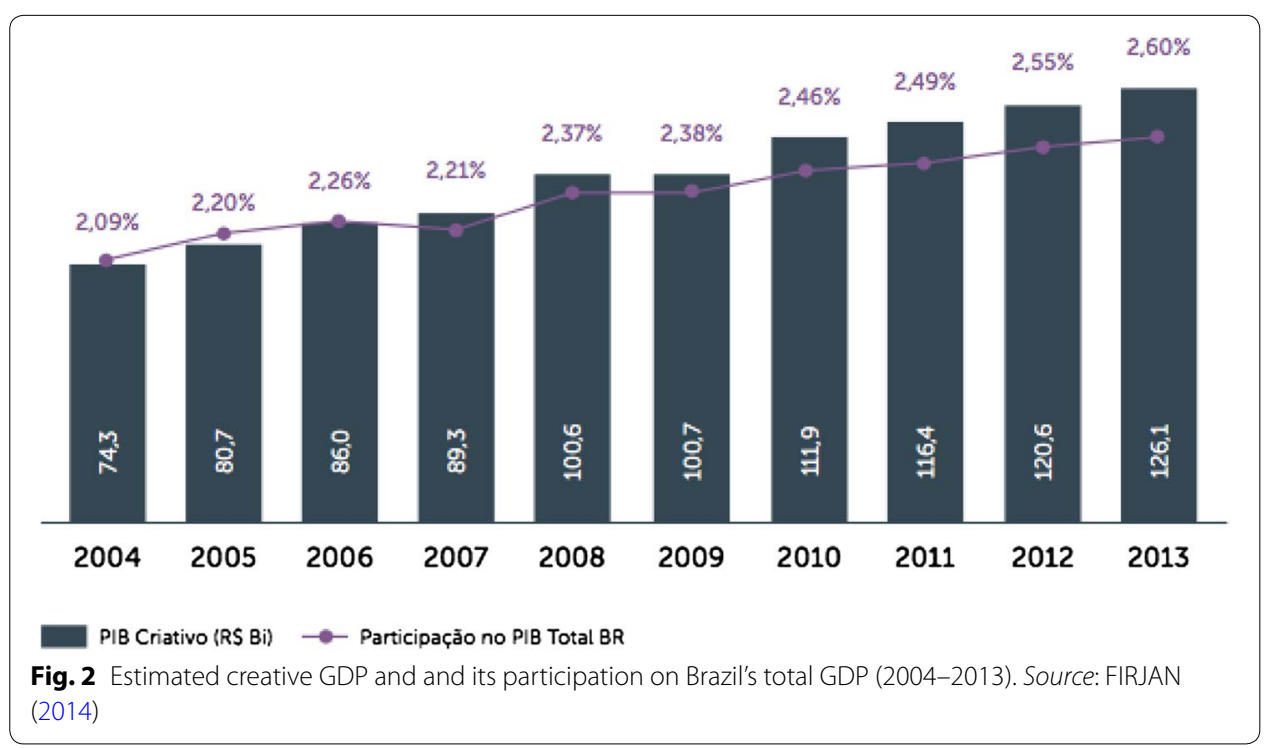




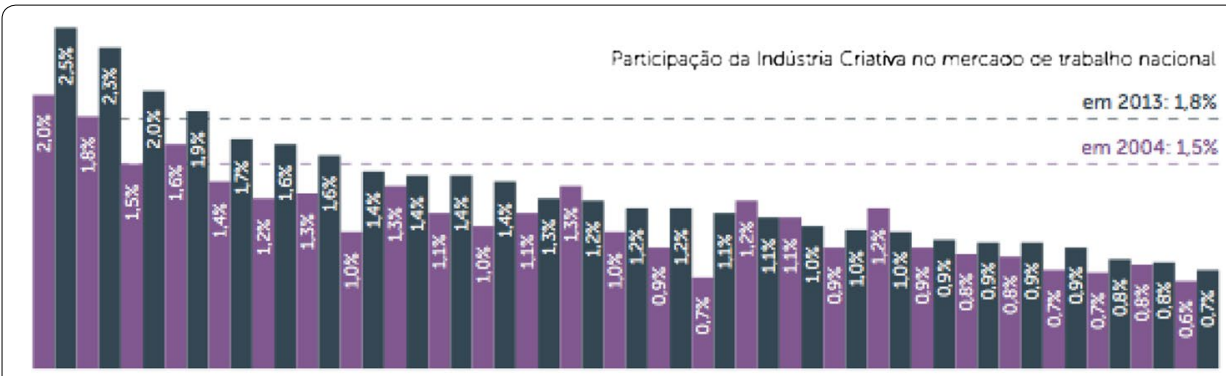

SP RJ SC RS DF PR MG CE AM ES PE BA SE GO RN TO RR PB MS PI AC MT PA MA RO AP AL

2004

Fig. 3 Participation of creative employees on the total amount of employees in the State (2004-2013). Source: FIRJAN (2014)
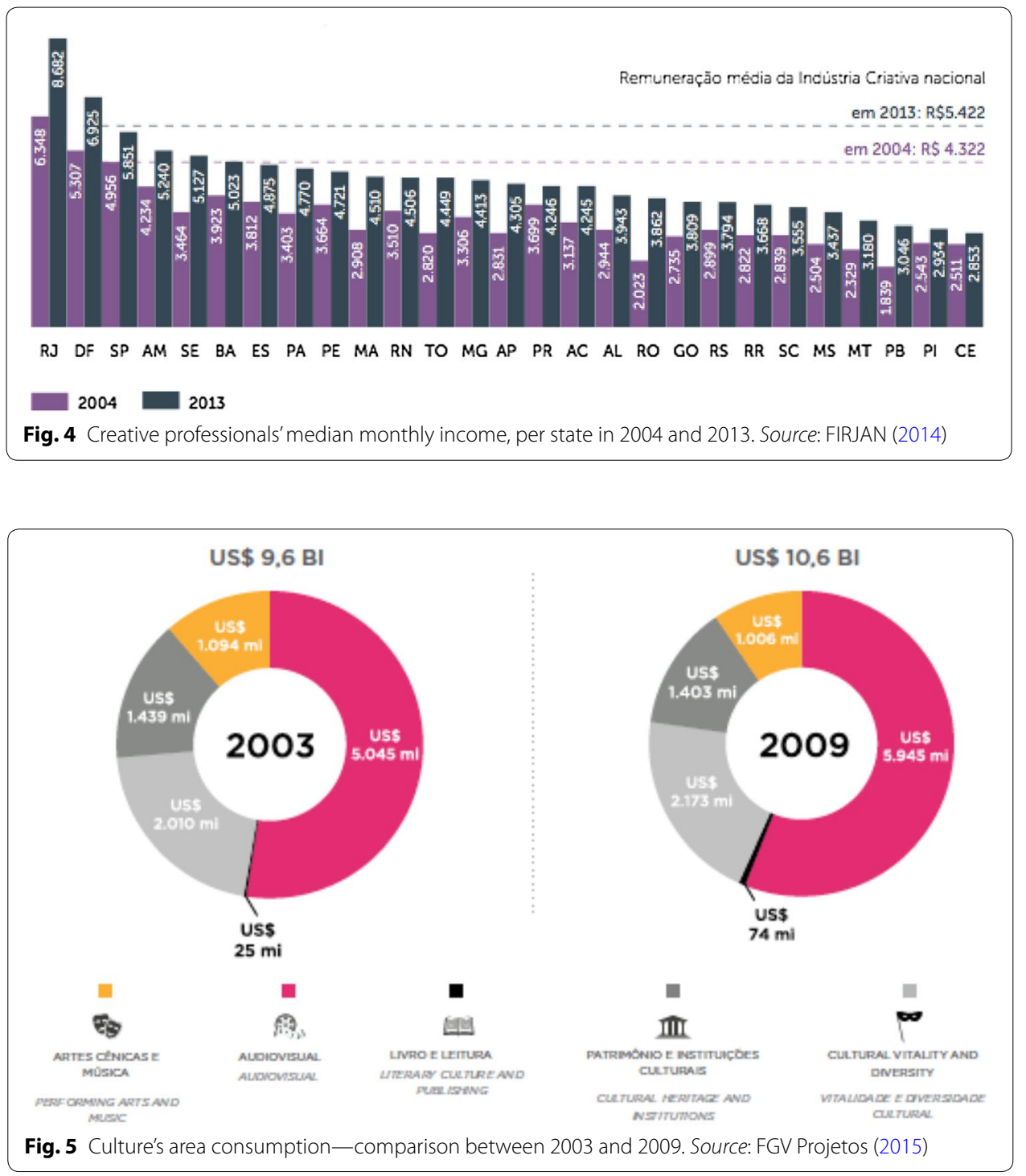
Both FGV and FIRJAN base their studies off of data on the formal market. However, if their data considered the cultural consumption generated by creative sectors of the informal economy, we would see that Brazilian creative economy is much bigger than the studies show.

The power and potential of the Brazilian creative economy is clear. The data presented above demonstrate its gradual growth and strengthening despite its being limited to an economy generated by formalized organizations that are recognized as legal entities. In practice, many entrepreneurs and professionals in creative sectors operate in the informal economy, which was not captured by these surveys. The impact of creative sectors in Brazil is thus underestimated as to their real economic movement. The informality in most of these cases occurs due to the immaturity of legal and institutional frameworks of these sectors and as a result of the relative lack of public policies and investments needed for the strengthening of the Brazilian creative economy, whether at the federal, state or municipal level.

\section{Public policies on creative economy in Brazil}

Despite the strategic potential of culture as a vector of development in the country, public cultural policies in Brazil still have a long way to go. From 2003 onwards, with Gilberto Gil as the Minister of Culture, there has been a widening of the conceptual scope and acting of this Ministry. There has been a wide process of empowerment in Brazilian civil society that gave birth to the National Plan of Culture [Plano Nacional de CulturaPNC], instituted by the law 12.243 in 2 December 2010. This document defines the concept of culture through a symbolic, civic and economic dimensions.

The subject of creative economy emerged in Brazil in 2004 during the XI Conference of UNCTAD in São Paulo via a panel dedicated exclusively to the question of creative industries from the perspective of developing countries. Nevertheless, the institutionalization of public policies in this field has been but gradual, reaching its peak with the creation of the Ministry of Culture's Secretary of Creative Economy.

During the realization of its 2011 Strategic Plan, the Secretary of Creative Economy [Secretaria de Economia Criativa-SEC] defined cultural diversity, sustainability, social inclusion and innovation as its principles for the formulation process of public policies for Brazilian creative economy. This "Brazilian creative economy" should be structured according to the comprehension of the need for the drafting of an endogenous model of development, one which would consider Brazil's characteristics and specificities as well those of its regions. The "importation" of international development models was soon discarded, although some references have been considered and adjusted to the Brazilian reality.

Although countries face common challenges regarding the theme of the creative economy, it is important to understand and identify the different stages and specific characteristics related to each country in order to formulate and implement effective, consistent, and structural policies.

However, the need to deepen the subject is imperative, especially considering the complexity of a field of studies whose transversality constitutes both its virtue and fragility. 


\section{Methodology}

The methodology used for the development of this work is of a qualitative nature, and descriptive as well as exploratory. The growing relevance of the creative economy has sparked a lot of bibliographic research, much of which is available on the CAPES online database.

Because it is a recent subject and because of its multidisciplinary nature, it has been treated by researchers from different knowledge areas that end up publishing in periodicals from the most distinct areas. Therefore, the choose to realize a survey on the articles through the "search by subject" mechanism in the CAPES 'website', being distinguished the following expressions associated with the theme: creative economy, creative industries, creative cities, creative classes, public policies on culture and creative economy. According to this procedure, it has been identified 58 publications, composed by 3 doctoral thesis, 2 dissertations and 53 scientific articles.

This bibliographic research was conducted using articles published by the CAPES Integrated System [Sistema Integrado CAPES-SICAPES] and classified into the following categories: A1, A2, B1 and B2. Of the 53 identified articles, 36 were published in periodicals within these categories, 19 were national, and 17 were international.

These 36 selected articles were then analysed one by one according to their themes, subthemes, objectives, and research methodologies so as to identify which aspects of creative economy were prioritized by researchers in the field. These analyses drew from the panorama of the most common research methodologies with the hope of shedding light on the areas that lacked depth and discussion as well as on methodologies that may be used in the future.

Of the 36 selected articles, 4 institutional documents were published by the governments of Brazil (Ministry of Culture) and Australia (Australia Council of Arts), 3 research reports by the Rio de Janeiro Federal Industries [Federação das Indústrias do Rio de Janeiro-FIRJAN], one by Getúlio Vargas Foundation [Fundação Getúlio Vargas-FGV] (FGV Projetos), and two by the United Nations Conference on Trade and Development (UNCTAD).

\section{Creative economy: results of the survey}

\section{Aspects and thematics/themes prioritized}

The incipient nature of the debates about creative economies can be observed by analyzing the volume and the characteristics of the articles selected for this work. Of the 36 articles in question, 10 deal with reflections on the concept of creative economy and its significance, congruencies, overlaps, divergences, related concepts, and applications in the formation and development of public policies; 12 focus on the relationship between creative economy and local and regional development through the investigations about creative cities, districts, and clusters; 8 articles present analyses related to issues faced by specific sectors of the creative economy; finally, 7 discuss management practices, models of decision-making, and dynamics associated with the professional work of creative sectors.

Bendassolli et al. (2009) conducted a theoretical review with the objective of presenting the theme [of creative economy] as promising for scientific research, drawing from a broad survey of concepts, features and characteristics defended by scholars and 
researchers of the field. Comparative analyses between concepts such as creative industries and cultural industries, content and copyright, and creative economy and economy of culture demonstrate the wide spectrum of meanings and characteristics that both clarify and confuse themselves. This porosity between concepts is reinforced by Serra and Fernandez (2014), whose work not only demonstrates how the concepts of culture economy, the knowledge economy, and the creative economy come together, but also recognizes this synthesis as a strategic factor capable of fostering productive inclusion and development for countries.

Corazza (2013) complements this discussion with an article-review that explores the reflections of internationally renowned authors that develop cross-disciplinary approaches critical of the phenomenon of the development of creative industries. Creative industries, creativity, innovation, culture, development, and the creative classes are some of the themes discussed in these analyses, which consider meanings and conceptual implications resulting from public development policies that create new dynamics of labour, new production processes, and reconfigure the marketing of cultural and creative goods and services.

In their analysis of the new market dynamics established in the context of creative industries, Bendassolli and Wood (2010) contribute critical reflections about the characteristics required by new careers. Although the discourse suggests the existence of a new professional that is autonomous and flexible, the criticisms raised by Bendassolli et al. emphasize the difficulties of adapting quickly to an everchanging world in which information and knowledge are infinite and become obsolete almost instantaneously. Bendassolli and Borges-Andrade (2011) also detail and analyze the meanings of work and of new professional profiles demanded by creative economy, scrutinizing the shift from a Canadian heuristic model of measurement in a way that allows them to identify aspects related to the centering of work in social norms, social relations, and lives of individuals. Even if this self-realization is present in most of the discourses of the professionals involved in these sectors, the precariousness of work relations stand out.

When considering the aforementioned points, one cannot help but wonder up to what point the creative economy and its industries are strategic for the development of favorable public cultural policies for cultural and symbolic production and whether individuals working in cultural sectors and citizen-consumers of cultural goods and services actually benefit. This is the question raised by Miller (2011), who highlights and criticizes ideological aspects that judge as potentially dangerous for the development of the cultural and creative field. Miller maintains that the expression "creative industries" masks a neoliberal politic that is permeated by a discourse of individualism and disengaged from social and collective issues.

In contrast to Miller's position, De Marchi (2014) offers an illuminating analysis of the Plan of the Secretary of the Creative Economy of the Brazilian Ministry of Culture and its process of going public cultural policies concerning creative economy. De Marchi's analysis seeks to distance itself from typical aspects of the strengthening of an ownership-based industry that is focused on copyrights-a hallmark of neoliberal markets. The term "Brazilian Creative Economy" reinforces principles associated with the vaporization of the country's cultural diversity and the promotion of innovation and sustainable, 
socially inclusive, and productive development, understanding the importance of networks and collectives as mediators of these processes.

Lima and Ortellado (2013) analyze the program Living Culture (Ministry of Culture) and the Law on the Promotion of Theater in the City of Sao Paulo in order to provoke a discussion on the promotion and financing of culture, highlighting the need to invest not only in the expansion of the consumption of cultural goods and services but also in the expansion of the right to produce culture.

Potts et al. (2008) propose a new definition of creative industries which, unlike the current English concept that is based on the creative nature of inputs and the intellectual property generated by its products, is based on a new market where supply and demand operate in complex social networks. This new definition advances the debate and broadens the concept of creative industries to its dynamic social dimension rather than restricting it to a static, sectoral, industrial gaze. From this perspective, the creative field is recognized as a complex system with multiple actors that interact at both microand macro-economic levels.

Another important element highlighted by Potts et al. is that creative industries share many of the same characteristics as the service economy, despite the former being characterized by its symbolic dimension that emerges out of cultural representations of society. It is thus necessary to understand them through an interdisciplinary vision of socio-economic complexes that integrate social sciences, behavioral and economic studies of anthropology, culture, and media among others.

In his consideration of territorial and urban development within creative economies, Pratt (2011) criticizes the concept of "Creative Cities" and highlights the tension between approaches geared to the development of strategies of place marketing and approaches aimed at a greater understanding of the identities and diversities of local cultures. Pratt raises a number of questions regarding the real (dis)advantages and benefits obtained from the implementation of policies designed to spur the growth of creative cities, either in the perspective of the city understood as space of cultural production and consumption or, from a spatial perspective, of creative solutions to local problems as well as for territorial governance models. The concept of Creative Cities is analyzed through an interrogation of its categories and features, which were often constructed, under a neoliberal bias, without a more in-depth look into issues associated with the social and economic inequality that results from processes such as gentrification. Pratt criticizes the "cake recipes" adopted and applied without a more detailed understanding of the differences between cities.

Like Pratt (2011), Bontje and Musterd (2009) criticize the concept of creative cities, which they believe is often restricted to the development of place branding strategies. For these authors, there exists within the concept of Creative Cities a prioritization of a highly skilled creative class over a less-educated population employed in declining sectors, which reinforces social inequalities rather than confronting and solving them. Policies for the development of cities as spaces of generators of creativity and knowledge are recognized, but more attention needs to be paid to the need to get away from readymade formulas that ignore local specificities.

In 2013, Pratt and Hutton expand their analyses of the relations between the creative economy and cities, investigating how creative economy has developed and been 
perceived as having potential for development even in periods of crisis, as was the case during the 2008 economic crisis. The authors analyze the association between the development of creative industries concentrated and the primacy of some cities over others, generating interregional disparities and growth. Many public managers and decision makers base their policies on territorial governance models rooted in fragile conceptualizations inadequate for the specificities of the creative economy and its sectors. Aspects and characteristics of traditional markets, in regard to its structure and its mode of organization, thus present themselves in a differentiated way when analyzed within the context of the creative economy and its dynamics.

In their article on the creative economy and urban development in Spain, Méndez et al. (2012) present a critical analysis of the creative sectors of Spain, its weight in the urban economy and its territorial distribution, considering different spatial scales and the levels of territorial concentration of activities of these sectors in various geographical spaces. Like Pratt and Hutton (2013), Mendez et al. credit the creative economy with a potentially relevant strategy to tackle the recent economic crisis faced by Europe. The symbolic aspect of this economy is highlighted by the value that it adds to its products impacting and renewing the urban image. The symbolic aspect of this economy is highlighted by the value that adds to its products [that are] impacting and renewing the urban image. Metropolitan regions appear as creative hubs as a function of the density of cultural, creative, and professional sectors in Spain, and within those regions we can identify groups in certain neighborhoods or areas that have generated synergy with urban renewal policies.

Leitão et al. (2010) enter the creative economy debate with a discussion on the formulation and implementation of policies to foster creative economy in the Northeastern region of Brazil. They use a draft methodology in order to identify creative territories in metropolitan and interstate sub-regions with high circulation and consumption of creative goods and services as well as high demographic, institutional, socioeconomic, and production density. The identification of these creative territories locates geographical areas with local and regional development potential related to the Northeast's creative economy.

This perspective on regional development is also found in the Corede Vale do Rio dos Sinos (Consinos) case study in Rio Grande do Sul, in which de Bem and Giacomini (2012) analyze the potential of Rio Grande do Sul's fourteen municipalities, developing medium-range development strategies in the region's footwear industry with the goal of reversing the negative impact that it has been suffering due to the importation of Chinese commodities. The fruit of German immigration to the region, the footwear production industry in Rio Grande do Sul experienced growth and success for more than three decades. Bem and Giacomini's study sought to identify creative activities of a complementary nature and with synergy potential for the development and production of footwear with high added value so as to make them competitive against foreign competition.

From a local development perspective, Bento Gonçalves may be analysed as a municipality with the potential to become a "Knowledge City." This possibility is based on the reflection of the convergence between the Brazilian creative economy model, which is supported by the Creative Economy Secretary from the Ministry of Culture as well as a knowledge-based development model, realized by the Generic Capital System taxonomy, 
which fosters information on systems integration of learning and providing knowledge (Fachinelli et al. 2014). The convergence between these two models rests in the theory that local culture is fundamental in this process and thus ought to be considered as a strategic vector for development.

Founded on an axis of creative economy and its sectors, the theme of development (be it local, regional, national, or global) is present in many other studies identified for the making of this article (Yusuf and Nabeshima 2005; Ren and Sun 2012; de Figueiredo Silva 2010; Golgher 2008). In these studies class, fostering strategies and cluster development or local productive arrangements are described as relevant for the strengthening of creative and innovative environments.

From a sectoral perspective, it is shown that studies, research, and reflections have prioritized sectors associated with so-called "new," digital medias such as films, television, music, digital games, and animations. This is perhaps because these sectors have been more impacted by the speed of changes on the internet field and therefore have more potential to widen markets and expand commercial possibilities. For example, the deverticalization of the productive chain of music is highlighted by Nakano (2010) as a process that advances and expands markets and opportunities for independent production that is directly impacted by technological innovations in recent decades.

Through an exploratory study on the animation industry in Brazilian television, Gatti Junior et al. (2014) emphasize and analyze a sector that has been strongly boosted both in Brazil and in the world, be it due to its technical quality and business management capacity, or to its existing in relatively favorable conditions relative to fin ancient opportunities and to the existence of multi-platform channels of diffusion.

While some sectors professionalize and become competitive in the global market, de Sousa Batista et al's study (2011) shows how contractual relations between the market and the comic artists from Ceará (a state in the Brazilian Northeast) are extremely precarious as a result of many professionals' unpreparedness to deal with issues related to the management of its formal and informal projects.

Lastly, in addition to the creative field themes and macroeconomic aspects discussed previously, many of which considered conceptual frameworks as well as territorial and sectoral development, it was determined within the selected articles an elevated interest in the following themes: apprenticeship and the generation of knowledge in communities and companies in creative sectors (Flach and Antonello 2011); interdisciplinarity and the integration of knowledge related to the theme of creative economy (Hartley 2011); the management of cultural and creative companies from an entrepreneurial perspective (Judice and Furtado 2014).

\section{Research methodologies used}

Of the 36 selected articles to conduct this bibliographic study, 31 were developed using qualitative methodologies, 1 used a mixed methodology, and the remaining 4 used quantitative methodologies. The predominance of studies and researches of qualitative nature is more than evident, especially considering that the majority of exploratory and descriptive studies are based in bibliographical researches focused on theoretical reflections or literature reviews. The conceptual imprecisions that these studies reveal about the research on creative economy have to be eradicated or minimized. The case studies 
also stand out as methods often used with the objective of deepening discussions on the theme as well as expanding theoretical reflections surrounding the emblematic or successful experiences resulting from the implementation of public policies designed to develop and foster the growth of territories, sectors, enterprises and professionals from the creative sectors.

As may be noted from the material analyzed for this study, there is still very little production of quantitative studies on the theme of creative economy. The Creative Economy Reports produced by the United Nations Conference on Trade and DevelopmentUNCTAD in 2008 and 2010 correspond to a first effort on the world data compilation on this economy. However, given that measurement methodologies are not standardized and that they vary from country to country, a comparative analysis becomes much more difficult to conduct.

\section{Conclusion}

The incipient and interdisciplinary nature of creative economy demands a deeper and more attentive consideration of the theme in such a way that establishes more accurate conceptual consistency as well as a collective, integrated, and effective construction of the theme. The constant overlapping between creative economy and other concepts still generates a series of confusions that hinder the demarcation of borders and scopes. The centrality of the concept of creative economy in its sectors in contrast to the centrality in their network dynamics and productive arrangements deserves a broader debate. The logic is neither binary nor exclusive, but rather of a more complex, inclusive nature. For a more comprehensive approach to be established, it is necessary to contemplates both the sectoral and territorial (be it physical or digital) nature. The fact that creative economy encompasses such a wide variety of sectors (ranging from patrimony to media) asks for an analysis of the existing specificities and differences between sectors as a way to avoid generalizing perspectives and approaches of and on the many different dynamics and realities that creative economy consists of. The comprehension of the economic networks and knowledge established among and within the diverse sectors of creative economy demand a closer examination of the types and intensities of connections as well as of cultural identities and dynamics within and between sectors.

The bibliographical research conducted and presented in this article demonstrates how a majority of the reflections produced on the theme of creative economy have been based on studies that utilize qualitative research methods. Theoretical and critical revisions, case studies, exploratory and descriptive research on the sectors, territories (cities and regions), and public policies have been developed through interviews with creative entrepreneurs, specialists, opinion leaders, institutional documents, and data reports in and on the field. Meanwhile, quantitative studies remain as a minority.

The lack of quantitative studies on the theme undermines the evolution of an economy that remains partially invisible due to the fact that its macroeconomic extent is not clearly measured. Instead of researching disaggregated data and information produced by data research institutes on geography and statistics for projections and estimates, it is necessary to establish a standardized sectoral classification and economic data measurement methodology that would enable comparative studies between national and 
regional analyses. Unfortunately, Brazil still doesn't have any measurement methodology on culture's satellite account, which would allow for a clearer understanding of the creative sector's' contribution to Brazil's total GDP.

The goal of this article is not to overvalue quantitative research at the expense of qualitative research, but rather to show the need for a larger multiplicity of approaches and research methodologies. Qualitative and quantitative research must be produced in complementary ways that deepen dialogue on the subject as well as expand both macroand micro-economic knowledge on the creative field, its actors, its practices, its impacts and its possibilities.

Authors' contributions

Competing interests

The authors declare that they have no competing interests.

\section{Publisher's Note}

Springer Nature remains neutral with regard to jurisdictional claims in published maps and institutional affiliations.

Received: 22 June 2016 Accepted: 27 July 2016

Published online: 18 April 2017

\section{References}

Australia (2013) Australia Council of the Arts. Creative Australia. http://creativeaustralia.arts.gov.au/assets/Creative-Australia-PDF-20130417.pdf. Last access: October, 2013

Bendassolli PF, Borges-Andrade JE (2011) Significado do trabalho nas indústrias criativas. RAE 51(2):143-159

Bendassolli PF, Wood Jr T, (2010) O paradoxo de Mozart: Carreiras nas indústrias criativas. Org Soc Salv 17(53):259-277. www.revistaoes.ufba.br

Bendassolli PF, Wood JrT, Kirschbaum C, Cunha MPE (2009) Indústrias criativas: definição, limites e possibilidades. RAE 49(1):010-018. ISSN 0034-7590

Bontje M, Musterd S (2009) Creative industries, creative class and competitiveness: Expert opinions critically appraised. Geoforum 40:843-852. www.elsevier.com/locate/geoforum

BRASIL (2008a) Ministério da Cultura. Caderno "Diretrizes Gerais para o Plano Nacional de Cultura", 2nd edn. Minc, Brasília

BRASIL (2008b) Ministério da Cultura Plano Nacional de Cultura: Diretrizes Gerais. Ministério da Cultura/Câmara dos Deputados, Brasília

BRASIL (2011) Ministério da Cultura. Plano da Secretaria da Economia Criativa: políticas, diretrizes e ações - 2011 a 2014. Ministério da Cultura, Brasília

Corazza RI (2013) Criatividade, inovação e economia da cultura: abordagens multidisciplinares e ferramentas analíticas. Rev Bras Inov 12(1):207-231

de Bem JS, Giacomini NMR (2012) As indústrias criativas como alternativa de retomada de crescimento: o caso do consinos no Rio Grande do Sul. Revista Brasileira de Gestão e Desenvolvimento Regional (G\&DR) 8(3):139-163

de Figueiredo Silva JL (2010) A emergência da geografia econômica das indústrias culturais. Geo UERJ Ano 121 (21). www.geouerj.uerj.br/ojs. ISSN 1981-9021

De Marchi L (2014) Análise do Plano da Secretaria da Economia Criativa e as transformações na relação entre Estado e cultura no Brasil. Intercom RBCC 37(1):193-215

de Sousa Batista PC, Paiva TA, Ramos RR, da Hora Almeida PC, Oliveira LGL (2011) As relações contratuais das indústrias criativas: o caso dos quadrinhos no Ceará. Cadernos Ebape. BR 9(2), article 8

Drake G (2003) This place gives me space: place and creativity in the creative industries. Geoforum 34:511-524. www. elsevier.com/locate/geoforum

Fachinelli AC, Carrillo FJ, D'Arisbo A (2014) Capital system, creative economy and knowledge city transformation: insights from Bento Gonçalves, Brazil. Expert Syst Appl 41:5614-5624. doi:10.1016/j.eswa.2014.02.0120957-4174/2014

Federação das Indústrias do Rio de Janeiro_FIRJAN (2008) A Cadeia da Indústria Criativa no Brasil. Rio de Janeiro: FIRJAN. http://www.firjan.org.br/data/pages/2C908CEC3286DF68013286FCB8CE2E1C.htm. Last access: September, 2013

Federação das Indústrias do Rio de Janeiro-FIRJAN (2011) A Cadeia da Indústria Criativa no Brasil Edição 2011. Rio de Janeiro: FIRJAN. http://www.firjan.org.br/data/pages/2C908CEC3286DF68013286FCB8CE2E1C.htm. Last access: 10 Sept 2013

Federação das Indústrias do Rio de Janeiro_FIRJAN (2014) Mapeamento da indústria criativa no Brasil. Rio de Janeiro: FIRJAN. WwW.firjan.org.br/economiacriativa. Last access: June 2015

FGV Projetos (2015) A cultura na economia brasileira The culture sector in Brazillian economy, vol 23. FGV, Rio de Janeiro

Flach L, Antonello CS (2011) Organizações culturais e a aprendizagem baseada em práticas. Cadernos EBAPE BR, 9(1), article 9 
Golgher AB (2008) As cidades e a classe criativa no Brasil: diferenças espaciais na distribuição de indivíduos qualificados nos municípios brasileiros. Rev Bras Est Pop 25(1):109-129

Hartley J (2011) Cultural studies and the urgency of interdisciplinarity: sooner, not later, we're going to need a cultural science. Matrizes 5(1):11-43

Hotho S, Champion K (2011) Small businesses in the new creative industries: innovation as a people management challenge. Manag Decis 49(1):29-54. doi:10.1108/00251741111094428

Hsueha S-L, Hsu K-H, Liua C-Y (2012) A multi-criteria evaluation model for developmental effectiveness in cultural and creative industries. Proc Eng 29:1755-1761. www.elsevier.com/locate/procedia

Jambeiro O, Ferreira F (2012) Compreendendo as Indústrias Criativas de Mídia: contribuições da economia política da comunicação. Rev Comun Mid 7(3):178-194

Judice VMM, Furtado SC (2014) Gestão de empreendimentos criativos e culturais: estudo de uma organização de ensino e difusão de ritmos afro-brasileiros em São João del-Rei (MG). Org Soc Salv 21(69):293-314. www.revistaoes.ufba.br

Junior WG, Gonçalves MA, Barbosa APFPL (2014) Um estudo exploratório sobre a indústria brasileira de animação para a TV. REAd 78(2):461-495

Kamel JAN, Souza FS (2012) Entretenimento Social Clube, engenharia de produção e economia da experiência. Sist Gest 7:288-297

Keane M, Ryan MD, Cunningham S (2005) Worlds apart? Finance and investment in creative industries in the Peoples Republic of China and Latin America. Telemat Inform 22:309-331. www.elsevier.com/locate/tele

Leitão CS, Guilherme LL, Oliveira LAG, Gondim RV (2010) Nordeste Criativo e desenvolvimento regional: esboço de uma metodologia para o fomento da economia criativa no nordeste brasileiro. Extraprensa (USP) 1:170-182

Lima L, Ortellado P (2013) Da Compra de produtos e serviços culturais ao direito de produzir cultura: análise de um paradigma emergente. DADOS Rev Ciênc Soc 56(2):351-382

Marcella M, Rowley S (2015) An exploration of the extent to which project management tools and techniques can be applied across creative industries through a study of their application in the fashion industry in the North East of Scotland. J Proj Manag (International Journal of Project Management), Int. doi:10.1016/j.ijproman.2014.12.002

Méndez R, Michelini JJ, Prada J, Tébar J (2012) Economía creativa y desarrollo urbano en España: una aproximación a sus lógicas espaciales. EURE 38(113):5-32

Miller T (2011) La nueva derecha de los estudios culturales - las industrias creativas. Tabula Rasa 15:115-135

Nakano D (2010) A produção independente e a desverticalização da cadeia produtiva da música. Gest Prod 17(3):627-638

Nicolaci-da-Costa AM (2011) O talento jovem, a internet e o mercado de trabalho na "Economia Criativa". Psicol Soc 23(3):554-563

Pardo CV, Literatura Brasileira Contemporânea: o desafio da exportação. Literatura Brasileira Contemporânea

Potts J, Cunningham S, Hartley J, Ormerod P (2008) Social network markets: a new definition of the creative industries. J Cult Econ 32:167-185. doi:10.1007/s10824-008-9066-y

Pratt AC (2011) The cultural contradictions of the creative city. City Cult Soc 2:123-130. www.elsevier.com/locate/ccs

Pratt AC, Hutton TA (2013) Reconceptualising the relationship between the creative economy and the city: learning from the financial crisis. Cities Int J Urb Policy Plan 33:86-95. www.elsevier.com/locate/cities

Prince R (2010) Fleshing out expertise: the making of creative industries experts in the United Kingdom. Geoforum 41:875-884. www.elsevier.com/locate/geoforum

Ren X, Sun M (2012) Artistic urbanization: creative industries and creative control in Beijing. Int J Urban Reg Res 36(3):504-521

Serra N, Fernandez RS (2014) Economia Criativa: da discussão do conceito à formulação de políticas públicas. Rev Adm Inov 11(4):355-372

Stolarick K, Currid-Halkett E (2013) Creativity and the crisis: the impact of creative workers on regional unemployment. Cities 33:5-14. www.elsevier.com/locate/cities

United Nations Conference on Trade and Development (UNCTAD). Creative economy report 2008. http://www.unctad. org/en/docs/ditc20082cer_en.pdf. Last access: Sept 2009

United Nations Conference on Trade and Development (UNCTAD). Relatório de Economia Criativa 2010. http://www2. cultura.gov.br/economiacriativa/relatorio-mundial-sobre-economia-criativa-em-portugues-ja-esta-disponivel-paraconsulta-e-download/. Last access: Sept 2013

Yusuf S, Nabeshima K (2005) Creative industries in East Ásia. Cities 22(2):109-122

\section{Submit your manuscript to a SpringerOpen ${ }^{\circ}$ journal and benefit from:}

- Convenient online submission

- Rigorous peer review

Immediate publication on acceptance

- Open access: articles freely available online

- High visibility within the field

- Retaining the copyright to your article

Submit your next manuscript at $>$ springeropen.com 